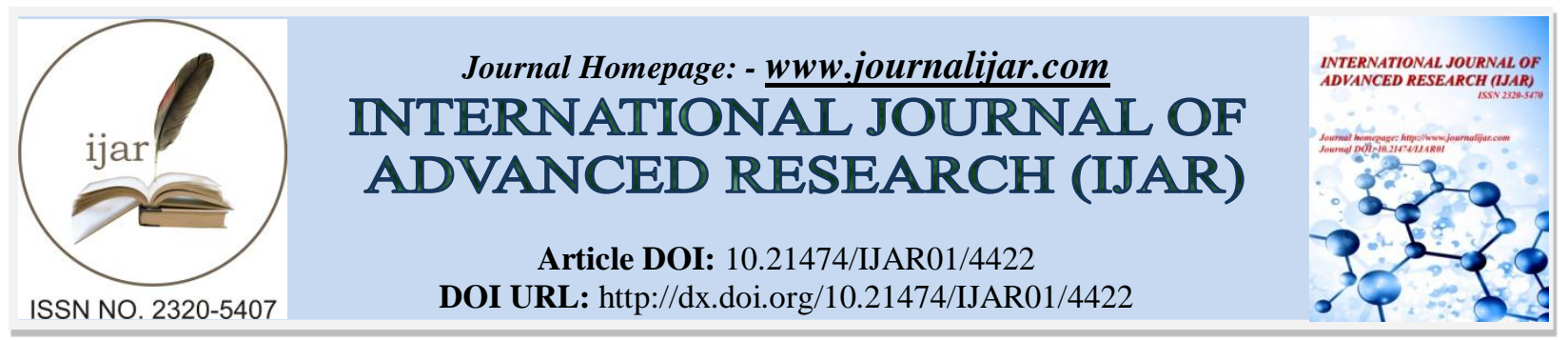

RESEARCH ARTICLE

\title{
THE EFFECTS OF A JATROPHA CURCAS-BASED AGROFORESTRY SYSTEM ON SOIL WATER DYNAMICS AND GROUNDNUT YIELD IN SUDANO-SAHELIAN ZONE, SENEGAL
}

\section{Ibrahima Diedhiou ${ }^{1}$, Fatou Kine Diop ${ }^{1}$,Modou Sene ${ }^{2}$, Roger Bayala ${ }^{1}$ and ${ }^{*}$ Papa Madiallacke Diedhiou ${ }^{3}$.}

1. Ecole Nationale Supérieure d'Agriculture (ENSA), BP A 296, University of Thiès, Sénégal.

2. Centre d'Etudes Régional pour l'Amélioration de l'Adaptation à la Sécheresse (CERAAS) BP 3320, Thiès, Sénégal.

3. UFR des Sciences Agronomiques d'Aquaculture et des Technologies Alimentaires (UFR S2ATA), Université Gaston Berger de Saint-Louis (UGB), Saint-Louis, Sénégal.

\section{Manuscript Info}

\section{Manuscript History}

Received: 09 April 2017

Final Accepted: 11 May 2017

Published: June 2017

\section{Key words:-}

Interaction, tree density, water balance, semi-arid, peanut basin Senegal, intercropping

\section{Abstract}

In the peanut basin, a major agricultural region in Senegal, crop yield has gradually declined in relation to soil degradation. Land use for food crops is a big in priority represents a big constraint for the intensive production of Jatropha curcas, a tree planted for biofuel. This study examined the possibility of designing appropriate agroforestry systems combining food crops and $J$. curcas. It was conducted in Nioro in the sub-humid zone of Senegal. Four treatments in complete randomized block design with three replications: groundnut-only crop, Jatropha curcas-only crop, groundnut-Jatropha curcas in combination at an interval of $6 \times 6 \mathrm{~m}$, and a groundnutJatropha curcas combination at an interval of $3 \times 3 \mathrm{~m}$ were compared. The influence of Jatropha curcas-based agroforestry systems on soil water dynamics was similar to that of a groundnut-only cropping system. No depressive effect on yields of groundnut and Jatropha was noticed.

Copy Right, IJAR, 2017,. All rights reserved.

\section{Introduction:-}

Biofuels are becoming increasingly important energy sources worldwide (Divakar et al., 2010). Consequently, interest is growing in Jatropha curcas (Euphorbiaceae), a plant adapted to arid and semi-arid conditions and producing oil rich kernels (Kaushik et al., 2007). This oil is easily converted into biofuel (Azam et al., 2005). In West Africa, several countries have opted to plant Jatropha curcas on a large scale to reduce dependence on fossil fuels, develop new agricultural industries and provide new sources of income for farmers (Azoumah and Blin, 2009). However, the development of biofuel in regions where arable land reserves are scarce could threaten food production (Azoumah and Blin, 2009). The peanut basin in Senegal, the number one region producer of millet and groundnuts and is also aimed for Jatropha curcas production.

The promotion of Jatropha curcas-based agroforestry systems combined with food crops could help to reconcile food production with biofuel production. Agroforestry systems not only increase the efficiency of rainwater use compared to monocropping (Lot et al., 2003), they also enhance crop water use efficiency by modifying microclimatic conditions (Brenner, 1996; Livesley et al., 2004). In addition, recent studies on the agroforestry system combining Guiera senegalensis with annual crops have shown that shrubs have a positive impact on 
maintaining soil fertility and yields (Lufafa et al., 2008) as well as on ensuring crops' water needs through hydraulic lift (Kizito et al., 2006; Kizito et al., 2007, Caldwell and Richards, 1989). Despite these potential benefits, other authors have reported negative effects of trees on combined crops due to competition for water (Mungai et al., 2001) or light as well as shading (Zomboudré et al., 2005).

The peanut basin is characterized by high rainfall variability, water is consequently critical to crop performance. To date, little data is available for this region on water consumption and the influence of Jatropha curcas on soil water dynamics and the water balance. Combining perennial and annual crops species in an agroforestry system in conditions of erratic rainfall requires a good understanding of the system's potential impact on soil water dynamics, yield of crops and water availability.

The objective of this study is to determine the optimal plantation density for Jatropha curcas with minimal competition effects on groundnut.

\section{Material and Methods:- Study site:-}

The study was conducted at the research station of the Senegalese Institute of Agricultural Research (ISRA) located in Nioro, $\left(13^{\circ} 45^{\prime} \mathrm{N}\right.$ and $\left.15^{\circ} 47^{\prime} \mathrm{W}\right)$, in the peanut basin.

The climate is of Sudano-Sahelian type, characterized by a dry season from November to May and a rainy season lasting from June to October. The rainfall pattern from 1989-2009 (20 years) indicates a variation between 500 and $1000 \mathrm{~mm}$, with an average of $738 \mathrm{~mm}$. The average annual temperature is about $28^{\circ} \mathrm{C}$ and average potential evapotranspiration is $1800 \mathrm{~mm}$ per year (Iyamuremye, 2000). The soil is classified as leached tropical ferruginous, with a depth limited by the hardpan layer observable at 1 meter. Soil structure is dominated by sand with a small proportion of clay (less than $20 \%$ ), and a low porosity (36-43\%). It is highly susceptible to compaction and has a low water retention capacity (Nicou et al., 1992).

\section{Plant Material:-}

The groundnut variety 73-33 recommended for the region was chosen for the experiments. It was sowed on July 3 , 2009 after the first rain. The field was weeded twice 15 days after sowing (DAS) and 40 DAS. Jatropha curcas trees were planted in 2007 with kernels from India.

\section{Experimental Design:-}

A complete randomized block design with four treatments was used :

- $\quad$ pure groundnut (PG), sowed at a density of 135,000 plants per hectare; this corresponds to intervals of $50 \mathrm{~cm}$ between rows and $15 \mathrm{~cm}$ between plants;

- $\quad$ pure Jatropha curcas (PJ), with trees planted at 3 x 3 m intervals, i.e., 1089 trees per hectare;

- $\quad$ combined groundnut / J. curcas with trees planted at 3 x 3 m intervals (C3X3);

- combined groundnut / J. curcas with trees planted at 6 x 6 m intervals (C6X6), i.e., 256 trees per hectare.

Each treatment was repeated three times and the test plot is represented by a 12 × $12 \mathrm{~m}$ square, i.e., a total of $144 \mathrm{~m}^{2}$.

\section{Measurements and observations:- \\ Soil moisture:-}

Soil water content was measured using a neutron moisture meter type $503 \mathrm{CPN}$. Repeated measurements were conducted using aluminum access tubes installed in the test plot. The depth profile was $180 \mathrm{~cm}$, due to the laterite hardpan layer. Soil profile measurements were made for each $10 \mathrm{~cm}$ every 15 days. Based on soil water content, stored water was calculated at the maximum rooting depth for groundnut, which is 1.1 meter (Kizito et al., 2007). The equation used to calculate the moisture density after the calibration of the probe was:

$\mathrm{HV}=0.6572 \times(\mathrm{Ns} / \mathrm{Ne})-0.0021\left(\mathrm{R}^{2}=0.99\right)$

$\mathrm{HV}$ : volumetric water content in $\mathrm{cm}^{3} / \mathrm{cm}^{3}$

Ns: neutron counting in the soil

Ne: neutron counting in water

The stored water was calculated using the following formula:

$\mathrm{S}=\mathrm{HV} \mathrm{x} \mathrm{dz}$

$\mathrm{S}$ : water storage in the soil in $\mathrm{mm}$ 
dz: soil depth in mm

Determining the water balance made it possible to calculate the water consumption under the different treatments for up to 42 days after sowing.

Because runoff was neglected, the water balance was calculated for the period 0-42 DAS and the soil horizon (0-180 $\mathrm{cm})$ where drainage was not observed, with the following formula:

$\mathrm{ETR}=\mathrm{P}-\Delta \mathrm{S}$

$\mathrm{P}$ : precipitation $(\mathrm{mm})$ is the main source of water for crops;

$\Delta \mathrm{S}$ : variation in soil water, for a given period;

ETR: actual evapotranspiration (mm).

The water consumption of crops (ETR) was calculated in absence of drainage, during the period 0-42 DAS, when the wetting front had not reached $180 \mathrm{~cm}$.

\section{Crop yields:-}

Jatropha curcas fruits were harvested at maturity (colour turned yellow then brown) from mid-August to midDecember. Fruits of the 4 plants located around each access tube were harvested every 15 days.The fruits were dried in an oven at $80^{\circ} \mathrm{C}$ for 5 days the total harvest for each plant was then weighed, the fruits counted, and peeled.

The groundnuts were harvested on October 24,2009 on plots of $15 \mathrm{~m}^{2}(1.5 \times 10)$ for each repetition of the three treatments. Groundnuts were then air dried for 20 days and shelled. The pod yield per plant was mesured.

\section{The land equivalent ratio:-}

The concept of land equivalent ratio (LER) initiated by Willey and Osiru (1972) has enabled a significant progress in the analysis of intercropping systems (Baldy and Stigter, 1997). It compares the yield of one crop in a monocrop system to its yield in an intercropping system. The LER is calculated using the following formula:

$\mathrm{LER}=\left(\mathrm{Y}_{1 \mathrm{i}} / \mathrm{Y}_{1 \mathrm{~m}}\right)+\left(\mathrm{Y}_{2 \mathrm{i}} / \mathrm{Y}_{2 \mathrm{~m}}\right)$

$\mathrm{Y}_{1 \mathrm{i}}$ : yield of crop 1 in intercropping system;

$\mathrm{Y}_{1 \mathrm{~m}}$ : yield of crop 1 in monocropping system;

$\mathrm{Y}_{2 \mathrm{i}}$ : yield of crop 2 in intercropping system;

$\mathrm{Y}_{2 \mathrm{~m}}$ : yield of crop 1 in monocropping system.

\section{Data Analysis:-}

Analyses of variance (ANOVA) were performed using the software Statistix to highlight the effects of combining Jatropha curcas with groundnut on soil water dynamics and yields of the species involved. Tukey test was performed for comparison of means at $5 \%$.

\section{Results:-}

\section{Soil water Dynamics:-}

The stored water was low for all treatments in samples from 0-110 $\mathrm{cm}$ before the first rainfall (-46 DAS) (Figure 1). At 28 DAS and 42 DAS, the opposite effect was observed. The stored water became higher in the PG and PJ treatments compared to $\mathrm{C} 3 \times 3$ and $\mathrm{C} 6 \times 6$ treatments. At 56 DAS, the stored water in the soil appeared to be the same quantity in all treatments, with a slight decrease in the PG treatment. Beyond 70 DAS, the water stored under the PJ treatment was the lowest. The treatments $\mathrm{C} 3 \times 3$ and PJ had the driest soil horizons between 110 and $180 \mathrm{~cm}$ until 42 DAS. Between 56 DAS and 98 DAS, the stored water became similar for all treatments. 

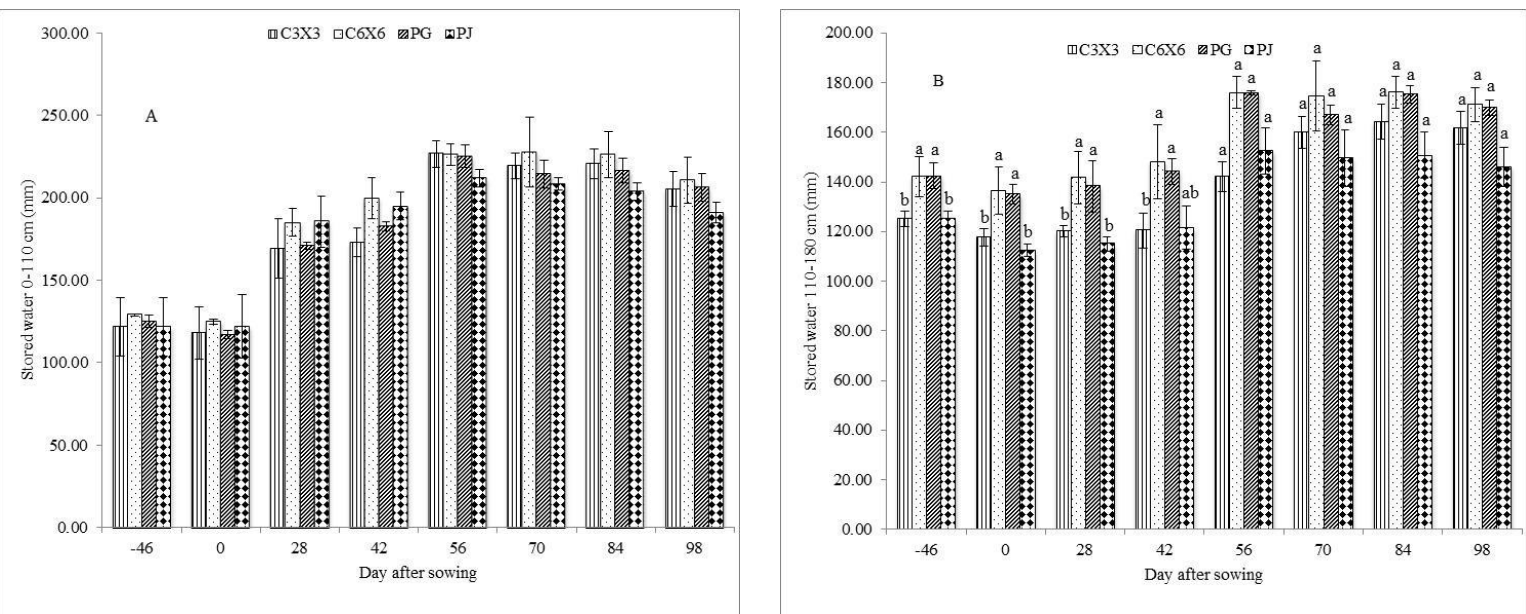

Figure 1:- Variation of water content in the horizon $01-110 \mathrm{~cm} \mathrm{(A)}$ and the horizon $110-180 \mathrm{~cm}(\mathrm{~B})$ according to the treatments and date of sowing [DAS: date of sowing; C3X3=intercropping $J$. curcas and groundnut with $J$. curcas planted at $3 \times 3 \mathrm{~m}$ intervals, C6X6=intercropping $J$. curcas and groundnut with $J$. curcas planted at $6 \times 6 \mathrm{~m}$ intervals; $\mathrm{PG}=$ pure groundnut; $\mathrm{PJ}=$ pure $J$. curcas $]$

\section{Water Balance:-}

With respect to water balance, at the beginning of the cycle (28 DAS), the consumption was almost identical for all the treatments (Table 1). However, there was slightly higher consumption in the treatment C3X3. Between July 31 and August 14, the trend remained the same. It was however to notice that consumption reached a peak of $3.6 \mathrm{~mm}$ day $^{-1}$ at 42 DAS for the treatment C3X3.

Table 1: Average daily water consumption $\left(\mathrm{mm} \mathrm{d}^{-1}\right)$ for crops according to treatments [C3X3=intercropping $J$. curcas and groundnut $J$. curcas planted at $3 \times 3 \mathrm{~m}$ intervals; C6X6=intercropping $J$. curcas and groundnut $J$. curcas planted at $6 \times 6 \mathrm{~m}$ intervals; $\mathrm{PG}=$ pure groundnut; $\mathrm{PJ}=$ pure $J$. curcas] (shows the average daily consumption of the different treatments from July 3 to July 31 and July 31 to August 14; July 3 is the day of sowing.)

\begin{tabular}{|l|l|l|l|l|}
\hline \multirow{2}{*}{ Periods } & \multicolumn{4}{|c|}{ Treatments } \\
\cline { 2 - 5 } & C3X3 & C6X6 & PG & PJ \\
\hline July 3-31 & $2.67 \pm 0.03$ & $2.26 \pm 0.01$ & $2.53 \pm 0.19$ & $2.27 \pm 0.26$ \\
\hline July 31-August 14 & $3.63 \pm 0.83$ & $2.87 \pm 1.13$ & $2.65 \pm 0.23$ & $2.76 \pm 1.20$ \\
\hline
\end{tabular}

Yield of Jatropha curcas:-

The number of fruits per plant varied from 29 for the $\mathrm{C} 3 \mathrm{X} 3$ treatment to a maximum of 34 for the PJ treatment (Table 2). The treatments had no significant effect on the yield parameter of Jatropha curcas.

Table 2:- Yield components for Jatropha curcas per treatment according to treatments [C3X3=intercropping $J$. curcas and groundnut with $J$. curcas planted at $3 \times 3 \mathrm{~m}$ intervals; C6X6=intercropping $J$. curcas and groundnut with J. curcas planted at $6 \times 6 \mathrm{~m}$ intervals; $\mathrm{PJ}=$ pure J. curcas]

\begin{tabular}{|l|c|c|c|c|c|c|c|c|}
\hline & $\begin{array}{c}\text { Number of fruits } \\
\text { per plant }\end{array}$ & $\begin{array}{c}\text { Number of } \\
\text { kernels per } \\
\text { plant }\end{array}$ & $\begin{array}{c}\text { Number } \\
\text { of kernels } \\
\text { per fruit }\end{array}$ & $\begin{array}{c}\text { Fruit } \\
\text { weight per } \\
\text { plant }(\mathrm{g})\end{array}$ & $\begin{array}{c}\text { Weight of } \\
\text { kernels per } \\
\text { plant (g) }\end{array}$ & $\begin{array}{c}\text { 100-kernel } \\
\text { weight }(\mathrm{g})\end{array}$ & $\begin{array}{c}\text { Weight } \\
\text { of fruit } \\
(\mathrm{g})\end{array}$ \\
\hline C3X3 & 29 & 66.17 & 2.63 & 43.54 & 26.68 & 44.25 & 1.53 & \\
\hline C6X6 & 29.92 & 68.58 & 2.62 & 45.61 & 27.93 & 41.19 & 1.46 & \\
\hline PJ & 34.5 & 73.83 & 2.61 & 52.32 & 31.49 & 43.11 & 1.52 & \\
\hline
\end{tabular}

\section{Groundnut pod yield per plant:-}

Pod yield of groundnut varied between $16 \mathrm{~g}$ and $21 \mathrm{~g}$ per plant (Figure 2). The effect of the treatments on the production of groundnut pods per plant was not significative. 


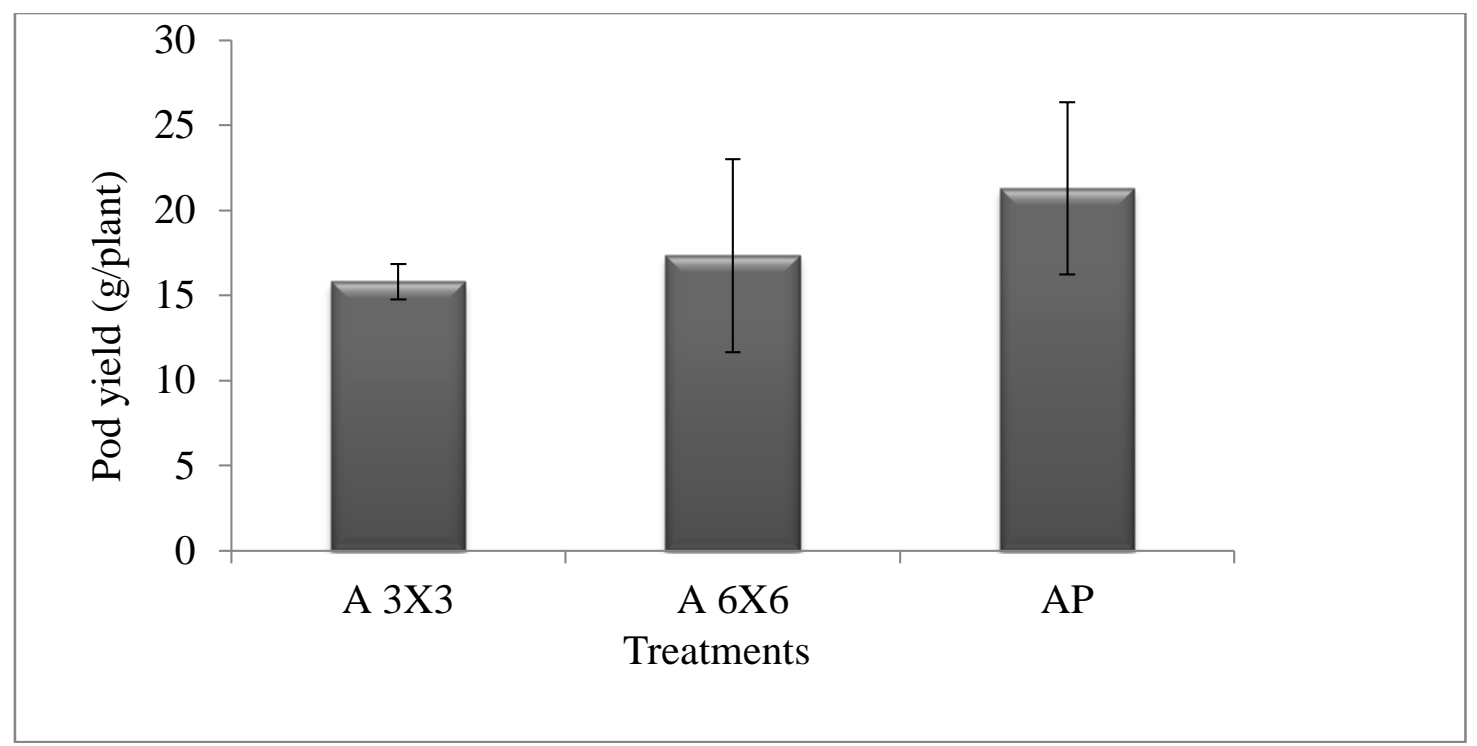

Figure 2:- Variations of pod yield (g/plant) according to treatments [C3X3=intercropping $J$. curcas and groundnut with $J$. curcas planted at $3 \times 3 \mathrm{~m}$ intervals, C6X6=intercropping $J$. curcas and groundnut with $J$. curcas planted at 6 x $6 \mathrm{~m}$ intervals, $\mathrm{PG}=$ pure groundnut, $\mathrm{PJ}=$ pure $J$. curcas $]$

\section{Land equivalent ratio (LER):-}

The LER values of the two intercropping systems were 2.4 for the $\mathrm{C} 3 \mathrm{X} 3$ treatment and 1.3 for the C6X6 treatment (Table 3). They are that greater than 1 reference value.

Table 3:- Variations of land equivalent ratio (LER) according to treatments [C $3 \mathrm{X} 3=$ intercropping $J$. curcas and groundnut with $J$. curcas planted at $3 \times 3 \mathrm{~m}$ intervals; C6X6=intercropping $J$. curcas and groundnut with $J$. curcas planted at $6 \times 6 \mathrm{~m}$ intervals; $\mathrm{PJ}=$ pure $J$. curcas $]$

\begin{tabular}{|c|c|}
\hline Treatments & Land equivalent ratio \\
\hline C3X3 & 2,4 \\
\hline C6X6 & 1,3 \\
\hline PG & 1 \\
\hline PJ & 1 \\
\hline
\end{tabular}

\section{Discussion:-}

The results of this study suggest that the combination of groundnut with Jatropha curcas does not have a significant effect on stored soil water compared to a groundnut-only cropping system. The planting density of $J$. curcas (1089 trees / ha or 256 trees / ha) did not influence this parameter. These observations corroborate those of Raddad and Luukkanen (2007) in a semi-arid region in Sudan, who reported no significant changes to stored water with the combination of Acacia senegal and sorghum or sesame compared to monocropping the annual crops. The same conclusion was drawn for the combination of Prosopis cineraria with Vigna radiata, and with Pennisetum glaucum in India (Singh et al., 2007). The advantages of associating Jatropha and groundnut in the same field could also be seen through the relatively high values of LER for C6X6 and C3X3 and treatments (LER >1).

In fact, intercropping is known to be beneficial when the LER value is greater than 1, meaning that the production per land surface unit is higher than for monocroping (Raddad and Luukkanen, 2007)..

It should however, be mentioned that early in the groundnut cycle, the deep horizons $(110-180 \mathrm{~cm})$ were significantly drier for the treatments involving Jatropha in a high tree density (C3x3 and PJ). This observation suggests complementarity in the use of soil water between $J$. curcas and groundnut. Jatropha trees appear to preferably draw water from deep horizons, while the annual crop i.e. groundnut was exploiting the surface horizons $(0-110 \mathrm{~cm})$ for water. This complementarity in water use has been previously reported for other agroforestry systems (Kizito et al., 2007). As a consequence, a higher water content is recorded for the deeper horizons $(110-350 \mathrm{~cm})$. 
Similar results were reported in agroforestry systems associating coffee with shade trees (Lin, 2010; Cannavo et al., 2011).

This study also showed that the combination with $J$. curcas did not reduce groundnut pod yield, even under high planting density of Jatropha curcas (1089 trees / ha). These results are in line with those of Noumi et al. (2011) who also found no negative effect on grain yield of cereal crops (Hordeum vulgare L., Triticum sativum L. and Triticum aestivum L.) under arid conditions (150 to $300 \mathrm{~mm}$ ) of Tunisia, when associated with Acacia tortilis ssp. raddiana. Raddad and Luukkanen (2007) found no negative effect of Acacia senegal on sesame and sorghum yields, when intercropping Acacia trees with two annual crops. Improvement of soil fertility under tree canopy should be added as other positive effect.

However, Kessler (1992) reported the opposite findings in terms of drop in sorghum yield under tree crowns, compared to the zone outside of influence the crown of Shea trees. Similar, results were also reported for maize in combination with Shea trees in a Sudano-Sahelian zone of Mali (Zomboudré et al., 2005). Yield reduction under tree canopies was associated with the decrease in light intensity due to a shading effect. A 50\% decrease in maize yield when combined with Gliricidia sepium and a $40 \%$ decrease in the association with Grevillea robusta were also reported (Odhiambo et al., 2001). This was related to competition for resources, particularly water that put maize at disadvantage.

In summary, the outcome of the interactions between trees and annual crops in agroforestry systems could be formulated as complex and related to different parameters. The tree may positively influence the annual crop depending on climatic conditions, soil type, topography, associated species and management methods of the crowns of the trees associated with the annual crop. Therefore, the findings in the present study for J. curcas and groundnut, may depend on soil and local climate conditions of the peanut basin. It is also noteworthy that the test site in Nioro registered a higher than average rainfall $(800 \mathrm{~mm}$, compared to an average of $700 \mathrm{~mm})$ during the experiment. It should also be added that the 3 years old J. curcas tree have not yet reached the full development of their crowns, estimated to be reached after 5 years (Wang, 2012). The competition effect of Jatropha tree for water and light could, in this conditions be speculated as not yet critical for the associated crops, explaining the lack of a depressive effect of intercropping on groundnut yield.

\section{Acknowledgments:-}

The authors are grateful to the African Union Commission and to European Union for financial assistance through " $10^{\text {th }}$ European Fund for Development" and African Union Research Grant (EU - financed grant contracts for external actions), grant contract $\mathrm{N}^{\circ}$ AURG/094/2012 CRS $\mathrm{N}^{\circ}$ 2012/289-014. The authors are thankful to Sidy SIDIBE for help in soil water data collection.

\section{References:-}

1. Azam M., Waris A., Nahar N. 2005: Prospects and potential of fatty acid methyl esters of some non-traditional kernel oils for use as biodiesel in India. Biomass Bioenerg, 29: 293-302.

2. Azoumah Y.K., Blin J. 2009: Recherche et développement sur les biocarburants en Afrique de l'Ouest: état des lieux et enjeux. Liaison Énergie-Francophonie, 82: 15-20.

3. Baldy C., Stigter C.J. 1997: Agrométéorologie des cultures multiples en régions chaudes. INRA Editions: Paris.

4. Brenner A.J. 1996: Microclimate modifications in agroforestry. In Tree Crop Interactions-A Physiological Approach, Ong CK, Huxley P (ed). CAB International: Wallingford; 159-187.

5. Caldwell MM, Richards JH. 1989: Hydraulic lift: water efflux from upper roots improves effectiveness of water uptake by deep roots. Oecologia, 79: 1-5.

6. Cannavo P., Sansoulet J., Harmanda J-M., Siles P., Dreyer E., Vaasta P. 2011: Agroforestry associating coffee and Inga densiflora results in complementarity for water uptake and decreases deep drainage in Costa Rica. Agr Ecosyst Environ, 140: 1-13.

7. Divakara B.N., Upadhyaya H.D., Wani S.P., Laxmipathi Gowda C.L. 2010: Biology and genetic improvement of Jatropha curcas L.: A review. Appl Energ, 87: 732-742

8. Iyamuremye F.G., Dick V, Diack R.P., Sène M., Badiane A., Diatta M. 2000: Carbon, Nitrogen and Phosphorus Mineralization Potential of Native Agroforestry Plant Residues in Soils of Senegal. Arid Soil Res Rehabil, 14: 359-371. 
9. Kaushik N., Kumar K., Kumar S., Kaushik N., Roy S. 2007: Genetic variability and divergence studies in kernel traits and oil content of Jatropha (Jatropha curcas L.) accessions. Biomass Bioenerg, 31: 497-502.

10. Kessler J.J. 1992: The influence of karité (Vitellaria paradoxa and néré (Parkia biglobosa) trees on sorghum production in Burkina Faso. Agroforestry systems, 17: 97-118.

11. Kizito F., Dragila M.I., Sène M., Lufafa A., Dick R.P., Diedhiou I., Dossa E., Khouma M., Ndiaye S., Badiane A. 2006: Seasonal soil water variation and root patterns among two semi-arid shrubs coexisting with Pearl millet in Senegal, West Africa. J Arid Environ, 67: 436-455.

12. Kizito F., Sène M., Dragila M.I., Lufafa A., Diedhiou I., Dossa E., Cuenca R., Selker J., Dick R.P. 2007: Soil water balance of annual crop-native shrub systems in Senegal's Peanut Basin. Agric Water Manage, 90: 137148.

13. Lin B.B. 2010: The role of agroforestry in reducing water loss through soil evaporation and crop transpiration in coffee agroecosystems. Agri Forest Meteorol, 150: 510-518.

14. Livesley S.J., Gregory PJ, Buresh R.J. 2004: Competition in tree row agroforestry systems. Soil water distribution and dynamics. Plant Soil, 246: 129-139.

15. Lott J.E., Khan A.A.H., Black C.R., Ong C.K. 2003: Water use in Grevillea robusta-maize over story agroforestry system in semi-arid Kenya. For Ecol Manage, 180: 45-59.

16. Lufafa A., Diédhiou I., Ndiaye S.A.N., Sène M., Khouma M., Kizito F., Dick R.P., Dossa E., Noller J.S. 2008: Carbon stocks and patterns in native shrub communities of Senegal's Peanut Basin. Geoderma, 146: 75-82.

17. Mungai D.N., Stigter C.J., Coulson C.L., Ng'ang'a J.K., Netondo G.W.S., Umaya G.O. 2001: Understanding yields in alley cropping maize (Zea mays L.) and Cassia siamea (Lam.) under semi-arid conditions in Machakos, Eastern Kenya. J Environ Sci, 13: 291-298.

18. Noumi Z., Abdallah F., Torre F., Michalet R., Touzard B., Chaieb M. 2011: Impact of Acacia tortilis ssp. raddiana tree on wheat and barley yield in the south of Tunisia. Acta Oecol, 37: 117-123.

19. Odhiambo H.O., Ong C.K., Deans J.D., Wilson J., Khan A.A.H., Sprent J.I. 2001: Roots, soil water and crop yield: tree crop interactions in a semi-arid agroforestry system in Kenya. Plant Soil, 235: 221-233.

20. Raddad E.Y., Luukkanen O. 2007: The influence of different Acacia Senegal agroforestry systems on soil water and crop yields in clay soils of the Blue Nile Region, Sudan. Agric Water Manag, 87: 61-72.

21. Singh G., Mutha S., Bala N. 2007: Effect of tree density on productivity of a Prosopis cineraria agroforestry system in North Western India. J Arid Environ, 70:152-163.

22. Wang, Z. (2012): Producing Jatropha biodiesel in China: policies, performance and challenges. In Jatropha, challenges for a new energy crop (pp. 95-121). Springer New York.

23. Willey R.W. and Osiru D.S. 1972: Studies of mixtures of maize and beans (Phaseolus vulgaris) with particular reference to plant population. J. Agric. Sci., 79: 517-529.

24. Zomboudré G., Zombré G., Ouedraogo M., Guinko S., Macauley H.R. 2005: Réponse physiologique et productivité des cultures dans un système agroforestier traditionnel: cas du maïs (Zea mays L.) associé au karité (Vitellaria paradoxa Gaertn.) dans la zone est du Burkina Faso. Biotechnol Agron Soc Environ, 9 (1): 75-85. 